\title{
Evaluation of COVID-19 Thorax Computed Tomography Findings in Hemodialysis Patients
}

\author{
Hemodiyaliz Hastalarında COVID-19 Toraks Bilgisayarlı Tomografi Bulgularının \\ Değerlendirilmesi
}

\author{
Ömer Faruk ATEŞ ${ }^{1}$ \\ (D) 0000-0002-0281-1128 \\ Erbil ARIK ${ }^{1}$ \\ (D) 0000-0002-5976-860X \\ Ogün TAYDAŞ ${ }^{2}$ \\ (I) 0000-0001-5966-2074 \\ Hamad DHEIR ${ }^{3}$ \\ (D) 0000-0002-3569-6269 \\ Fatih GÜNEYSU ${ }^{4}$ \\ (D) 0000-0002-8433-3763
}

\begin{abstract}
${ }^{1}$ Sakarya Training and Research Hospital Department of Radiology, Sakarya, Turkey

${ }^{2}$ Haydarpaşa Numune Training and Research Hospital Department of Family Medicine, Istanbul, Turkey

${ }^{3}$ Sakarya University Faculty of Medicine Department of Internal Medicine, Sakarya, Turkey

${ }^{4}$ Sakarya Training and Research Hospital Department of Emergency Medicine, Sakarya, Turkey
\end{abstract}

\section{Corresponding Author Sorumlu Yazar \\ Ömer Faruk ATEŞ \\ omfarat@hotmail.com}

Received / Geliş Tarihi : 10.08.2020 Accepted / Kabul Tarihi : 18.10.2020 Available Online /

Çevrimiçi Yayın Tarihi : 25.11.2020

\begin{abstract}
Aim: Coronavirus disease 2019 (COVID-19) is an unprecedented cause of pandemics affecting all segments of society. It is not known whether hemodialysis patients form a different patient group in terms of susceptibility to COVID-19 infection or severe disease. In this study, thorax computed tomography (CT) findings were evaluated in hemodialysis patients diagnosed with COVID-19 infection during the pandemic period.

Material and Methods: CT findings of 32 hemodialysis patients diagnosed with COVID-19 with real-time polymerase chain reaction or thorax CT examination were evaluated retrospectively. Radiological findings were classified as ground glass, consolidation, mixed type involvement (ground glass and consolidation), crazy paving appearance, interlobular septal thickening, nodule, halo-reverse halo finding, air bronchogram finding, subpleural curvilinear opacities and tree-in-bud views.

Results: A total of 32 patients were included in the study. Twenty-one $(65.6 \%)$ of the patients were male and $11(34.4 \%)$ were female. The mean age was $67.5 \pm 8.5$ years. All patients had chronic kidney failure. Thorax CT examination revealed ground-glass opacities in $14(43.8 \%)$ patients, consolidation in $3(9.4 \%)$ patients, and mixed type involvement (ground-glass opacities and consolidation) in $15(46.9 \%)$ patients. The accompanying CT findings were pleural effusion in $23(71.9 \%)$ patients, subpleural curvilinear opacities in $13(40.6 \%)$ patients, bronchial wall thickening in $11(34.4 \%)$ patients, lymphadenopathy in $7(21.9 \%)$ patients, bronchiectasis in $4(12.5 \%)$ patients and pleural thickening in $4(12.5 \%)$ patients.

Conclusion: When hemodialysis patients are infected with COVID-19 infection, they differ significantly from other COVID-19 patients in terms of symptoms, clinical course, and prognosis, as well as imaging findings.
\end{abstract}

Keywords: COVID-19; hemodialysis; pneumonia; computed tomography.

\section{ÖZ}

Amaç: Koronavirüs hastalığ1 2019 (coronavirus disease 2019, COVID-19) toplumun her kesimini etkileyen benzeri görülmemiş bir pandemi sebebidir. Hemodiyaliz hastalarının, COVID-19 enfeksiyonuna ya da şiddetli hastalığa yatkınlık açısından farklı bir hasta grubunu oluşturup oluşturmadıkları bilinmemektedir. Bu çalışmada pandemi döneminde COVID-19 enfeksiyonu tanısı alan hemodiyaliz hastalarında toraks bilgisayarlı tomografi (BT) bulguları değerlendirilmiştir.

Gereç ve Yöntemler: Gerçek zamanlı polimeraz zincir reaksiyonu veya toraks BT incelemesi ile COVID-19 tanısı konulan 32 hemodiyaliz hastasının BT bulguları geriye dönük olarak değerlendirildi. Radyolojik bulgular; buzlu cam, konsolidasyon, karışık tip tutulum (buzlu cam ve konsolidasyon), kaldırım taşı görünümü, interlobüler septal kalınlaşma, nodül, halo-ters halo bulgusu, hava bronkogram bulgusu, subplevral kürvilineer opasiteler ve tomurcuklanmış ağaç görünümleri olarak sınıflandırıldı.

Bulgular: Çalışmaya toplam 32 hasta dahil edildi. Hastaların 21'i $(\% 65,6)$ erkek, 11 'i $(\% 34,4)$ kadındı. Yaş ortalaması $67,5 \pm 8,5$ yıl idi. Tüm hastalarda kronik böbrek yetmezliği mevcuttu. Toraks BT incelemesinde hastaların 14'ünde $(\% 43,8)$ buzlu cam görünümü, 3'ünde $(\% 9,4)$ konsolidasyon ve 15 'inde $(\% 46,9)$ karışık tip tutulum (buzlu cam görünümü ve konsolidasyon) görüldü. Eşlik eden BT bulguları $23(\% 71,9)$ hastada plevral effüzyon, $13(\% 40,6)$ hastada subplevral kürvilineer opasiteler, $11(\% 34,4)$ hastada bronşiol duvar kalınlaşması, $7(\% 21,9)$ hastada lenfadenopati, $4(\% 12,5)$ hastada bronşektazi ve $4(\% 12,5)$ hastada plevral kalınlaşma idi. Sonuç: Hemodiyaliz hastaları COVID-19 enfeksiyonuna yakalandıklarında semptom, klinik seyir ve prognostik açıdan olduğu gibi görüntüleme bulguları açısından da diğer COVID-19 hastalarından önemli farklılıklar göstermektedir.

Anahtar kelimeler: COVID-19; hemodiyaliz; pnömoni; bilgisayarlı tomografi. 


\section{INTRODUCTION}

The severe acute respiratory syndrome coronavirus 2 (SARS-CoV-2), known as coronavirus disease 2019 (COVID-19) has spread rapidly all over the world, causing a serious pandemic. The prognosis of the disease varies from asymptomatic or very mild course to unilateral or bilateral severe pneumonia and even respiratory failure that will require respiratory support in intensive care conditions. In severe cases, the severe inflammatory response accompanied by cytokine storm worsens respiratory symptoms and can even cause death. Although the mortality of the disease in the general population varies between $1.4 \%$ and $8 \%$, the proportion of patients who need intensive care support rises to high values between $16 \%$ and $78 \%$ (1). Advanced age, male gender, and current comorbidity (especially cardiovascular disease, diabetes, chronic obstructive pulmonary disease, and cancer history) are poor prognostic factors associated with the disease (1).

Since symptoms are non-specific for diagnosis in COVID-19 pneumonia, some diagnostic tests are required in addition to the patient's clinic. Real-time polymerase chain reaction (RT-PCR) is the standard test in diagnosis. However, since there is a waiting period for the detection of the virus and can be negative results at the beginning of the disease, radiological evaluation often plays a key role in the diagnosis (2).

Some specific radiological findings have been identified in computed tomography (CT) examination in COVID-19 pneumonia. These findings are in the form of bilateral, peripheral, and ground-glass opacities, consolidations, or a combination of these, which mainly hold the basal regions (3). CT findings were divided into 4 groups by the British Society of Thoracic Imaging (BSTI). This classification is used frequently by adapting it to our country, where the first case was seen on March 10, 2020. The course of the infection in chronic kidney patients is not clear. Mortality is expected to be higher in hemodialysis (HD) patients compared to the general population due to poor prognostic criteria such as advanced age, comorbidities, etc. Considering the high number of HD patients and the immune function of these patients is not normal, the condition of HD patients is of particular importance in the COVID-19 pandemic $(1,4)$.

In this study, we aimed to evaluate the findings in the thorax CT examination of HD patients diagnosed with COVID-19 infection during the pandemic period.

\section{MATERIAL AND METHODS}

\section{Patient Selection}

Patients who were diagnosed with COVID-19 and admitted to our hospital with respiratory symptoms between 31 March and 25 May 2020 were evaluated. It was observed that 2513 patients had thoracic CT examinations at the time of admission. Among these patients, chronic HD patients diagnosed with COVID-19 were investigated. Patients were diagnosed with the presence of clinical signs (fever, cough, etc.) and positive thorax CT findings, or at least one positivity of RT-PCR test. Typical COVID-19 or possible COVID-19 categories were based on the classification determined by the BSTI as positive thorax CT findings. Finally, 32 patients who met the criteria were included in the study.
Comorbidities that patients carry in addition to chronic kidney failure were classified as a history of hypertension, diabetes, cardiovascular disease, COPD, and cancer.

The study was approved by the Ethics Committee of Sakarya University Faculty of Medicine (27.07.2020, 450).

\section{Thorax CT Examination}

In all patients, images were obtained with a multi-section CT device with 64 detectors $(5 \mathrm{~mm}$ slice thickness, $512 \times 512$ matrix, $120 \mathrm{Kv}$ automatic modulation $\mathrm{mA}$; Aquilion64, Toshiba Medical Systems, Japan). Thorax CT examinations were evaluated by two independent radiologists (with 10 years of CT experience, Boardcertified, and 4 years of CT experience). After the images were evaluated independently, the consensus was achieved in evaluation differences.

\section{Image Analysis}

Radiological findings were classified as ground glass, consolidation, mixed type involvement (ground glass and consolidation), crazy paving appearance, interlobular septal thickening, nodule, halo-reverse halo finding, air bronchogram finding, subpleural curvilinear opacities and tree-in-bud views. Also, the presence of accompanying findings such as cavitation, bronchiectasis, bronchial wall thickening, pleural changes (thickening, effusion), lymphadenopathy, and pneumothorax was evaluated. Opacities in which signs of the vascular or bronchial wall could be distinguished were defined as ground glass, and opacities that were not distinguishable were defined as consolidation. Round or irregular shaped, ground glass density with uniform or irregular borders, semi-solid, or solid densities measured at 3 centimeters and below were accepted as nodules.

\section{Statistical Analysis}

MedCalc v.12 (Ostend, Belgium) was used for statistical analysis. The descriptive statistics were given as mean \pm standard deviation. Categorical variables were stated as frequencies and percentages.

\section{RESULTS}

A total of 32 patients were included in the study. Twentyone $(65.6 \%)$ of the patients were male and $11(34.4 \%)$ were female. The mean age of the patients was $67.5 \pm 8.5$ years. All patients had chronic kidney failure. The comorbidities present in the patients in order of frequency include hypertension in $30(93.8 \%)$ patients, diabetes in 16 $(50.0 \%)$ patients, cardiovascular disease in $16(50.0 \%)$ patients, chronic obstructive pulmonary disease in 8 (25.0\%) patients and cancer history in $2(6.3 \%)$ patients (Table 1). The malignancies present in these two patients were prostate and laryngeal cancers. In the follow-up, 11 (34.4\%) patients died, while the remaining 21 (65.6\%) patients were discharged after treatment.

Table 1. Comorbidities of the patients $(n=32)$

\begin{tabular}{lc}
\hline Comorbidities & $\mathbf{n}(\boldsymbol{\%})$ \\
\hline Hypertension & $30(93.8)$ \\
Diabetes & $16(50.0)$ \\
Cardiovascular Disease & $16(50.0)$ \\
Chronic Obstructive Pulmonary Disease & $8(25.0)$ \\
Cancer & $2(6.3)$ \\
\hline
\end{tabular}


In the thorax CT examination, $14(43.8 \%)$ patients had ground-glass appearance (Figure 1), 3 (9.4\%) patients consolidation, and $15(46.9 \%)$ patients mixed type appearance (ground glass and consolidation). Air bronchogram was observed in $12(37.5 \%)$ patients and all of them consisted of patients with consolidation or mixed type involvement. Nodules were observed in the lung parenchyma of $5(15.6 \%)$ patients (Figure 2). Interlobular septal thickening was observed in $6(18.8 \%)$ patients, but the crazy-paving pattern was not observed in any of the patients. Tree-in-bud pattern was observed in $6(18.8 \%)$ of the patients, and $5(83.3 \%)$ of these patients had mixedtype involvement, while only 1 patient had a ground-glass appearance, and none of them had pure consolidation. While the halo sign was not observed in any of the patients, the reversed halo sign was observed in one $(3.1 \%)$ patient (Figure 3). The accompanying CT findings were pleural effusion in $23(71.9 \%)$ patients, subpleural curvilinear opacities in $13(40.6 \%)$ patients, bronchial wall thickening in $11(34.4 \%)$ patients, bronchiectasis in $4(12.5 \%)$ patients, and pleural thickening was observed in $4(12.5 \%)$ patients. None of the patients had cavitation or pneumothorax (Table 2).

\section{DISCUSSION}

Our study is very important in terms of being one of the first studies showing the COVID-19 thorax CT findings in HD patients, which is a very special population. One of the most important results of our study was the presence of ground glass, consolidation, or mixed type (the most common) involvement in all patients. In our patient group, unlike the CT findings reported in the normal population in

Table 2. Computed tomography findings of the patients n $(\%)$

\begin{tabular}{lc}
\hline Primary Findings & \\
Pure Ground Glass Opacity & $14(43.8)$ \\
Pure Consolidation & $3(9.4)$ \\
Mixed Type & $15(46.9)$ \\
Crazy Paving Pattern & $0(0.0)$ \\
Reticular Pattern & $6(18.8)$ \\
Interlobular Septal Thickening) & $5(15.6)$ \\
Nodule & $0(0.0)$ \\
Halo sign & $1(3.1)$ \\
Reverse Halo Sign & $12(37.5)$ \\
Air Bronchogram & $13(40.6)$ \\
Subpleural Curvilinear Lines & $6(18.8)$ \\
Tree in Bud & \\
Accompanying Findings & $0(0.0)$ \\
Cavitation & $4(12.5)$ \\
Bronchiectasis & $11(34.4)$ \\
Bronchial Wall Thickening & $23(71.9)$ \\
Pleural Effusion & $4(12.5)$ \\
Pleural Thickening & $7(21.9)$ \\
Lymphadenopathy & $0(0.0)$ \\
Pneumothorax &
\end{tabular}

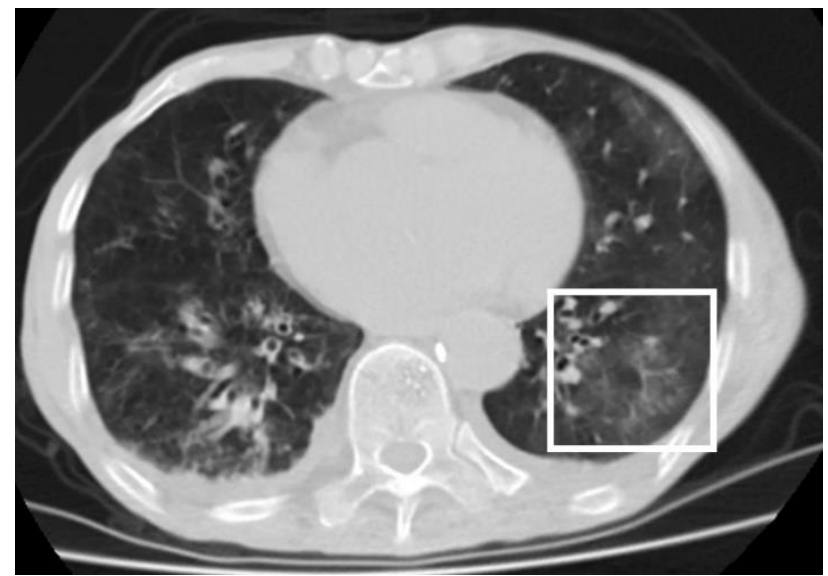

Figure 1. Axial non-contrast computed tomography image shows ground-glass opacity in the left lower lobe (frame).

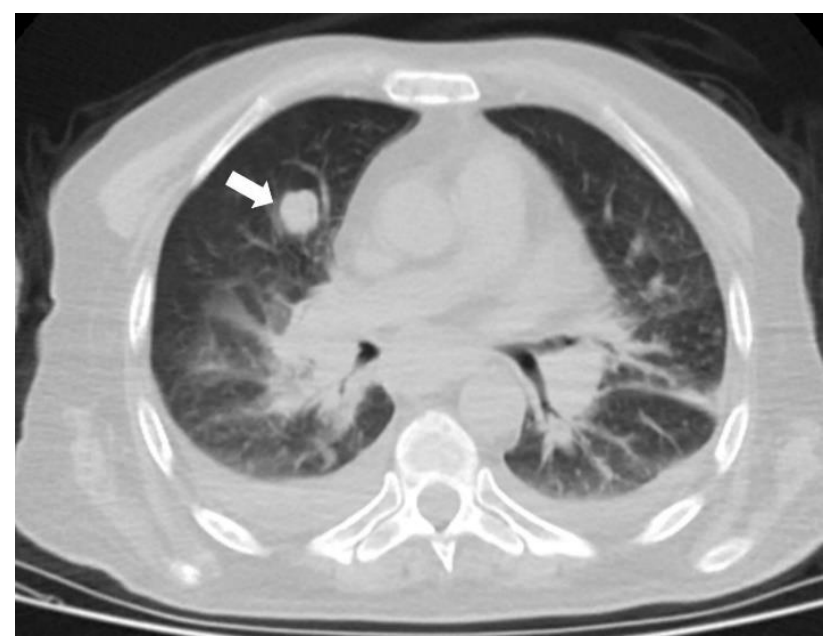

Figure 2. Axial non-contrast computed tomography image shows a nodule in the right lower lobe (arrow).

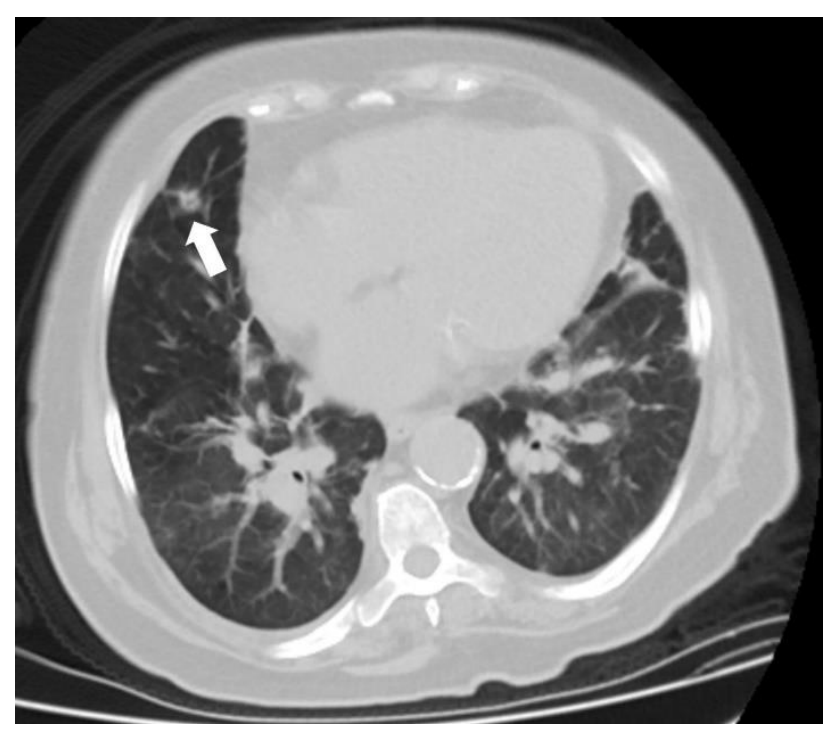

Figure 3. Axial non-contrast computed tomography image shows the reversed halo sign in the right middle lobe (arrow). 
the literature, consolidations accompanying ground-glass appearance were more common than pure ground-glass opacities, and pleural effusion was also more frequent. These findings were evaluated in favor of the higher disease stage and more severe infection at the time of diagnosis in HD patients with COVID-19 infection. Besides, it was observed that the tree-in-bud appearance was more frequent in our patient group compared to the non-specific COVID-19 patient group in the literature. This finding suggests that bacterial pneumonia or aspiration pneumonia may have accompanied COVID-19 pneumonia in our patient group due to the presence of comorbidities in addition to chronic kidney disease, the more severe infection, and that the stage of the disease is more advanced than other patients. Similarly, a higher rate of pleural pathology may indicate that the infection is at an advanced stage in our patient group, or it may be a sign of poor prognosis.

COVID-19 disease, the cause of which is SARS-CoV-2, was declared as a pandemic by the World Health Organization on 12 March 2020. As of April 8, 2020, the virus has been reported to affect more than 199 countries worldwide, infecting more than one million people and causing around 81500 deaths. However, since some patients with asymptomatic and mild symptoms have not been tested, the stated figures are considered to be under reality (5).

Since the symptoms in COVID-19 pneumonia are nonspecific for diagnosis, other diagnostic tests are required in addition to the clinical findings of the patients. RT-PCR is the standard test in diagnosis (2). However, thorax CT examination plays a complementary and key role in the diagnosis because RT-PCR does not give immediate results. It can give false-negative results due to low viral load and it is about 5 days between false-negative result and positive result. CT is very important in early diagnosis, especially in the patient group in which the patient's symptoms persist for more than 3 days and the RT-PCR test is negative due to the low viral load $(5,6)$. However, it has been shown that CT findings may be normal in $56 \%$ of patients in the first 2 days from the onset of symptoms (7).

A wide variety of findings have been described in different studies of COVID-19 lung involvement. However, the most common CT finding in all studies was typically reported as ground-glass opacities with peripheral and subpleural distribution. In the majority of patients, multilobar involvement, especially the lower lobes, has been demonstrated. Ground-glass opacities are defined as fog-shaped density increases in which the vascular and bronchial walls are not erased and can be found alone, with areas of consolidation or in the form of a crazy-paving pattern with an interlobular septal thickening. Consolidations, on the other hand, are defined as increased density due to exudate filling into the alveoli and blurring the vascular and airway boundaries. They are usually observed in patients with multifocal, segmental and patchy involvement with COVID-19 infection $(5,8)$. Other typical CT findings include nodules, reticular pattern (interlobular-intralobular septal thickening), air bronchogram, airway changes (bronchiectasis, bronchiolar wall thickening), halo and reverse halo sign, while atypical findings are a tree-in-bud pattern, subpleural curvilinear opacities, lymphadenopathy, pleural changes (thickening, effusion) and cavitation $(2,8)$. Round or irregular shaped, ground glass density with uniform or irregular borders, semi-solid, or solid densities measured at 3 centimeters and below are defined as nodules (9). The reticular pattern refers to interlobular and intralobular septal thickening reflecting interstitial lymphocyte infiltration (10). While ground glass appearances surrounding the consolidation areas, halo finding, represents hemorrhage around the mass or nodule; the consolidation areas surrounding the ground glass areas, reverse halo finding, represents the dissolution of the debris from the central section $(8,10)$. HD patients form a special group of patients because they constitute a large patient population, have associated comorbidities, have impaired immune function, and have the potential to become super-infectious when infected $(1,4)$. Some studies have shown that COVID-19 enters cells through the angiotensin-converting enzyme-2 (ACE-2) receptor, causing infection. The abundance of ACE-2 receptors in renal proximal tubule cells in uremic patients is one of the factors that predispose HD patients to infection (11).

After the SARS-CoV-2 virus infects the respiratory tract, it multiplies in the cells of the airway and activates the immune system and causes the release of massive levels of pro-inflammatory cytokines. The resulting cytokine storm can cause severe symptoms and even death. IL-6, IL-10, TNF-a, and other inflammatory cytokine increases are associated with poor prognosis in COVID-19 infection (12). Since lymphocyte and granulocyte functions are impaired in HD patients due to their uremic status, the immune response to COVID-19 infection is abnormal (13). In one study, T cells, B cells, and natural killer (NK) cells were found to be lower in patients who received HD treatment compared to patients who did not. In HD patients with COVID-19 infection, the number of these cells has been shown to decrease even more. Similarly, the number of cytokines such as IL-4, IL-6, and TNF- $\alpha$ increased in patients with COVID-19 infection compared to a healthy population, while the rate of these cytokines in HD patients with COVID-19 infection decreased significantly compared to other patients with COVID-19 infection. These results revealed that the impaired immune response in HD patients had a devastating effect on initiating an effective anti-viral response while limiting tissue damage as it reduced cytokine release. In the same study, the main causes of death of HD patients with COVID-19 were determined as cardiovascular and cerebrovascular complications or hyperkalemia. The reason for this has been shown to be shortened dialysis times to reduce the risk of COVID-19 infection of HD patients (4).

Considering the pathogenesis of lung involvement findings in COVID-19 infection and changes in the immune system response in HD patients, it is not known whether the frequency of lung involvement findings will differ in this group of patients. In the study by Wang et al. (14), bilateral diffuse consolidation or groundglass appearances were observed in all 7 HD patients who were diagnosed with COVID-19, and death was reported in 3 of the patients. In the study of Du et al. (11) with 32 COVID-19 positive HD patients, ground-glass opacities were observed in 18 cases; unilateral consolidations were 
observed in 7 patients, bilateral consolidations were observed in 7 patients; and pleural effusion was observed in 2 patients. In the study by Wang et al. (13) involving 5 patients, ground-glass opacities were observed in all patients, and it was reported that no severe complications or death occurred in any patient. In our study, a combination of ground glass and consolidation was observed in the majority ( $46.9 \%$ ) of patients.

In the study conducted by $\mathrm{Ma}$ et al. (4), deaths were reported in 10 of $42 \mathrm{HD}$ patients who were positive for COVID-19. In our study, the mortality rate was $11 / 32$ $(34.4 \%)$. Studies, including our study, show that HD mortality due to COVID-19 is quite high compared to the other population.

Ground glass opacities have been reported between $46 \%$ and $100 \%$ in COVID-19 infection and occur in the early phases of the disease or mild infection. As the severity of the disease increases, a crazy-paving pattern occurs with consolidation or interstitial thickening within the ground glass areas $(15,16)$. In our study, the consolidations accompanying the ground-glass areas (mixed type involvement) were observed to be higher than pure consolidation with a rate of $46.9 \%$, and the pure consolidation rate was lower than other COVID-19 CT studies, which were not specific to HD patients. This situation was interpreted in favor of the disease stage or severity of inflammation in HD patients when compared to the other patient population. It is associated with pure consolidation in COVID-19 infection, long time between symptom onset and thoracic CT examination, or advanced (>50 years) patient age $(17,18)$. In our study, pure consolidation was observed in $3(9.4 \%)$ patients. The crazy paving pattern is a common finding for COVID-19 infection and has been reported between $5 \%$ and $89 \%$ (15). In the later stages of the infection, it is stated that this pattern progresses to consolidation or causes the development of pleural effusion (17). The absence of a crazy-paving pattern and high pleural effusion in our patient group was associated with the advanced stage of infection in HD patients at the time of diagnosis.

Air bronchogram is also one of the frequently observed findings in COVID-19 infection, and it was reported as high as $80 \%(41 / 51)$ in a study by Song et al (19). Bronchial wall thickening has been reported to be higher in patients with severe clinical symptoms compared to patients with mild symptoms (20). In our study, air bronchogram findings were found in 12 (37.5\%) patients, and bronchial wall thickening was found in 11 (34.4\%) patients. Another frequently reported finding in COVID-19 infection is nodules. It was reported as $6 \%$ in the study by Shi et al. (21), and 7.2\% (with or without halo sign) in the study by Li et al (22). In our study, nodules were seen in $5(15.6 \%)$ patients and it was observed higher than these studies. It has been suggested that in the reticular pattern, reticulations increase with prolonged disease duration $(17,23)$. Reticular pattern and linear opacities are reported in the literature at a very variable rate between $1 \%$ and $81 \%$ (15). Inter-intralobular septal thickening and linear opacities were observed in 14 $(43.8 \%)$ patients in our study. Reverse halo finding is among the findings in COVID-19 infection. In the studies conducted, Bernheim et al. (7) reported as low as 2/121 $(1.7 \%)$, while Wang et al. (24) reported a higher rate with
14/93 (15.1\%). In our study, a reverse halo sign was observed in $1(3.1 \%)$ patient.

Although it has been stated that tree-in-bud appearances, which are defined as bronchiolitis findings in the literature, can also be seen in COVID-19 infection, it is stated that bacterial infection superposition or aspiration should be considered first if this finding is observed (15). In our study, this finding was observed in $6(18.8 \%)$ patients, and it was thought that bacterial pneumonia or aspiration pneumonia might accompany these patients due to the presence of comorbidities or advanced infection-disease stage in our patient group.

Mediastinal lymphadenopathy (LAP) is one of the rare CT findings in COVID-19 infection and has been stated to be a risk factor for severe and progressive pneumonia. LAP has been reported in the literature between $0 \%$ and $29 \%$. It is stated that when it is seen with pleural effusion and tree in bud pattern views, it should be evaluated in favor of bacterial superinfection (15). In our study, mediastinal LAP was seen in 7 (21.9\%) patients and is consistent with the rate reported in the general COVID 19 population in the literature.

Pleural pathologies (effusion and thickening) are rare, associated with pleural inflammation and observed in the late stages of the disease. They are also thought to be a poor prognostic marker and reported between $0 \%$ and $20 \%$ in COVID-19 infection $(15,25)$. In our patient group, pleural effusion was observed in $23(71.9 \%)$ patients, pleural thickening was observed in $4(12.5 \%)$ patients, and pleural effusion and/or thickening was observed in 25 $(78.1 \%)$ patients and was above the reported rates.

Our study has some important limitations. The first of these is that the study is retrospective, single centered, and not comparative. The presence of comorbid diseases in most HD patients appears to be another limitation in revealing the specific differences of these patients to chronic renal failure or regular dialysis treatment. Also, the low number of patients is an important limitation in terms of the adequacy of statistical data.

\section{CONCLUSION}

HD patients are a special group of patients due to differences in the immune system, a high number of comorbidities, and periodic HD requirements. When these patients are infected with COVID-19, they differ significantly from other COVID 19 patients in terms of symptoms, clinical course, and prognostic as well as imaging findings. In our study, it was shown that mixed patterns (ground glass and consolidation coexistence), nodules, budded tree views, and the presence of pleural pathology were more common than other COVID-19 patients.

Ethics Committee Approval: The study was approved by the Ethics Committee of Sakarya University Faculty of Medicine (27.07.2020, 450).

Conflict of Interest: None declared by the authors.

Financial Disclosure: None declared by the authors.

Acknowledgements: None declared by the authors. 


\section{REFERENCES}

1. Goicoechea M, Sánchez Cámara LA, Macías N, Muñoz de Morales A, Rojas ÁG, Bascuñana A, et al. COVID-19: clinical course and outcomes of 36 hemodialysis patients in Spain. Kidney Int. 2020;98(1):27-34.

2. Akçay Ş, Özlü T, Yılmaz A. Radiological approaches to COVID-19 pneumonia. Turk J Med Sci. 2020;50(SI1):604-10.

3. Xu YH, Dong JH, An WM, Lv XY, Yin XP, Zhang JZ, et al. Clinical and computed tomographic imaging features of novel coronavirus pneumonia caused by SARS-CoV-2. J Infect. 2020;80(4):394-400.

4. Ma Y, Diao B, Lv X, Zhu J, Liang W, Liu L, et al. COVID-19 in hemodialysis (HD) patients: Report from one HD center in Wuhan, China. medRxiv. doi: 10.1101/2020.02.24.20027201.

5. Hani C, Trieu NH, Saab I, Dangeard S, Bennani S, Chassagnon $\mathrm{G}$, et al. COVID-19 pneumonia: A review of typical CT findings and differential diagnosis. Diagn Interv Imaging. 2020;101(5):263-8.

6. Huang P, Liu T, Huang L, Liu H, Lei M, Xu W, et al. Use of chest CT in combination with negative RT-PCR assay for the 2019 novel coronavirus but high clinical suspicion. Radiology. 2020;295(1):22-3.

7. Bernheim A, Mei X, Huang M, Yang Y, Fayad ZA, Zhang N, et al. Chest CT Findings in coronavirus disease-19 (COVID-19): Relationship to duration of infection. Radiology. 2020;295(3):200463.

8. Özdemir M, Taydaş O, Öztürk MH. Thorax computed tomography findings in COVID-19 infection. J Biotechnol and Strategic Health Res. 2020;4(Special Issue):91-6.

9. Hansell DM, Bankier AA, MacMahon H, McLoud TC, Müller NL, Remy J. Fleischner Society: glossary of terms for thoracic imaging. Radiology. 2008;246(3):697-722.

10. Ye Z, Zhang Y, Wang Y, Huang Z, Song B. Chest CT manifestations of new coronavirus disease 2019 (COVID-19): a pictorial review. Eur Radiol. 2020;30(8):4381-9.

11. Du X, Li H, Dong L, Li X, Tian M, Dong J. Clinical features of hemodialysis patients with COVID-19: a single-center retrospective study on 32 patients. Clin Exp Nephrol. 2020;24(9):829-35.

12. Gong J, Dong H, Xia Q, Huang Z, Wang D, Zhao Y, et al. Correlation analysis between disease severity and inflammation-related parameters in patients with COVID-19 pneumonia. medRxiv. doi: 10.1101/2020.02.25.20025643

13. Wang R, Liao C, He H, Hu C, Wei Z, Hong Z, et al. COVID-19 in hemodialysis patients: A report of 5 cases. Am J Kidney Dis. 2020;76(1):141-3.

14. Wang R, He H, Liao C, Hu H, Hu C, Zhang J, et al. Clinical outcomes of hemodialysis patients infected with severe acute respiratory syndrome coronavirus 2 and impact of proactive chest computed tomography scans. Clin Kidney J. 2020;13(3):328-33.

15. Ufuk F, Savaş R. Chest CT features of the novel coronavirus disease (COVID-19). Turk J Med Sci. 2020;50(4):664-78.

16. Ates OF, Taydas O, Dheir H. Thorax magnetic resonance imaging findings in patients with coronavirus disease (COVID-19). Acad Radiol. 2020;27(10):1373-8.

17. Xiong Y, Sun D, Liu Y, Fan Y, Zhao L, Li X, et al. Clinical and high-resolution CT features of the COVID-19 infection: Comparison of the initial and follow-up changes. Invest Radiol. 2020;55(6):332-9.

18. Zhu T, Wang Y, Zhou S, Zhang N, Xia L. A comparative study of chest computed tomography features in young and older adults with coronavirus disease (COVID-19). J Thorac Imaging. 2020;35(4):W97-101.

19. Song F, Shi N, Shan F, Zhang Z, Shen J, Lu H, et al. Emerging 2019 novel coronavirus (2019-nCoV) pneumonia. Radiology. 2020;295(1):210-7.

20. Li K, Fang Y, Li W, Pan C, Qin P, Zhong Y, et al. CT image visual quantitative evaluation and clinical classification of coronavirus disease (COVID-19). Eur Radiol. 2020;30(8):4407-16.

21. Shi H, Han X, Jiang N, Cao Y, Alwalid O, Gu J, et al. Radiological findings from 81 patients with COVID19 pneumonia in Wuhan, China: a descriptive study. Lancet Infect Dis. 2020;20(4):425-34.

22. Li K, Wu J, Wu F, Guo D, Chen L, Fang Z, et al. The clinical and chest $\mathrm{CT}$ features associated with severe and critical COVID-19 pneumonia. Invest Radiol. 2020;55(6):327-31.

23. Pan Y, Guan H, Zhou S, Wang Y, Li Q, Zhu T, et al. Initial CT findings and temporal changes in patients with the novel coronavirus pneumonia (2019-nCoV): a study of 63 patients in Wuhan, China. Eur Radiol. 2020;30(6):3306-9.

24. Wang J, Xu Z, Wang J, Feng R, An Y, Ao W, et al. CT characteristics of patients infected with 2019 novel coronavirus: association with clinical type. Clin Radiol. 2020;75(6):408-14.

25. Zhao W, Zhong Z, Xie X, Yu Q, Liu J. Relation between chest CT findings and clinical conditions of coronavirus disease (COVID-19) pneumonia: A multicenter study. Am J Roentgenol. 2020;214(5):1072-7. 